\title{
CHLORIDE CHANNELS AND THE REACTIONS OF CELLS TO TOPOGRAPHY
}

\author{
G.Tobasnick and A.S.G.Curtis* \\ Centre for Cell Engineering, University of Glasgow, Glasgow, UK
}

\begin{abstract}
The reactions of rat epitenon cells to substratum topography on the micrometric and nanometric scale such as grooveridge structures include cell extension, elongation and orientation reactions. In this paper we report that stretchsensitive chloride channels may be involved in the earliest stages of these reactions in epitenon fibroblast-like cells. We report that rat epitenon-cells can develop appreciable lateral mechanical tension that could stretch both the force generating cells themselves and those nearby. We show that cells in medium in which more than $80 \%$ of the chloride has been replaced by nitrate show little reaction to topography. Spreading of the cells takes place but is much reduced along the direction of the groove-ridge topography but enhanced across the topography. The chloride channel inhibitors NPPB (5-Nitro-2- (3phenylpropylamino) benzoicacid) 4,4'-disothiocyanostilbene-2, 2' sulphonic acid (DIDS) and Chlorotoxin produce similar results which are further accentuated when these inhibitors are presented in low chloride medium. An antibody against $\mathrm{ClC} 3$, which has close homology to $\mathrm{ClC} 5 / 6$ also, blocked reaction to topography. These treatments have no significant effect on cell spreading on planar surfaces nor do they lead to changes in internal $\mathrm{pH}$ in the cells. There is a slight inhibition of rates of cell movement. Experiments using antisense oligoribonucleotides to $\mathrm{ClC}-5$ or $\mathrm{ClC}-6$ channel m-RNA also inhibit topographic reactions, which provides further confirmation of the hypothesis. Since the $\mathrm{ClC}-3,4$ and 5 share considerable sequence similarities in the genes and in their proteins it has not been possible to make an unambigous determination of which precise chloride channel(s) is (are) involved.
\end{abstract}

Key Words: Microtopography, chloride channel, antisense, contact guidance, tendon cells.

*Address for correspondence:

A.S.G.Curtis

Centre for Cell Engineering, Joseph Black Building,

University of Glasgow, University Avenue,

Glasgow G12 8QQ, UK

Telephone number: ++44 (0)141 3305147

Fax number: ++44 (0)1413303730

E-mail: A.Curtis@bio.gla.ac.uk

\section{Introduction}

A wide variety of cell types react to the topography of the substratum by changes in morphology (Clark et al., 1987, 1990), cytoskeletal organisation (Clark et al., 1987, 1990), movement (Curtis and Wilkinson, 1998), phagocytic activity and tyrosine kinase activation. (Wojciak-Stothard et al., 1996). But little is known about the actual mechanism of the reaction though several theories have been proposed regarding the feature(s) of the topography that influence the cells to make these reactions. It is fairly certain that the reaction is to topography and not to preferentially adsorbed molecules affecting substratum adhesion or chemical signaling to the cells. The reason for this conclusion that it is a direct reaction to topography is based on the fact that cells react similarly to the same topographies made in very different materials in high or low serum conditions (Curtis and Wilkinson, 1998) and that chemical signals competed against topography are overcome by deep topographies. Cells grown in planar culture are often under self-generated mechanical tension (Harris, 1982; Britland et al., 1996; Pelham and Wang, 1999; Raucher and Sheetz, 2000), and this appears also to be true when the cells are grown on grooves (Sero and Riehle, unpublished results).

This paper reports investigations on the nature of the signal that leads to the reactions of the cells to topography. In this paper we started from the possibility that cells are reacting to tension, self-generated by their attempts to spread on the topography. Various observations show that the cells generate appreciable mechanical tensions such that the cells 'snap' back if they lose an adhesion at one end of the cell (Harris, 1982). If this is the case we might expect stretch receptors to play an important role in the reactions of cells to topography.

We have approached the possibility that stretch receptors are directly involved in the reaction by looking at cell reactions to topography in the presence of changed levels of chloride and other ions and in the presence of various inhibitors of chloride channels and of antisense RNAs against chloride channel expression.

A considerable number of the chloride channels that have been sequenced are classified as 'stretch receptors' or 'putative stretch receptors' in the Swiss Protein database (Web reference 1). The IDEST database (Web reference 2, Bassett Douglas et al., 1992) finds homology between the mec-5 stretch receptors in Caenorhabditis elegans and chloride channel ClC-5 in rats. Ludewig et al. $(1996,1997)$ described the $\mathrm{ClC}-0(\mathrm{ClCN}-0)$ channel as an asymmetrical paired channel capable of three states of response. Middleton and his colleagues (1996) obtained a very similar result. This channel is a voltage-gated channel, which is 
fairly widely expressed which can give three different signal levels. It has much homology with other members of the voltage-gated $\mathrm{ClC}$ channels. The asymmetric pairs capable of three output states is exactly the type of system that would function as a stretch receptor as $\mathrm{x} y$ comparisons have to be made to detect stretch.

The experiments we report start with a description of the effects of low chloride levels in the medium on the reactions of cells to groove-ridge topography, test of the effects of some of the known chloride channel inhibitors and finally the effects of appropriate antisense RNA to chloride channels. The results are compared with reactions on planar substrata.

\section{Materials and Methods}

\section{Microstructured surfaces}

Fabrication by photolithography and dry etch methods. Fused silica slides $1 \mathrm{~mm}$ thick (Multi-lab, Newcastle, UK) were cut into $25 \mathrm{~mm}^{2}$ samples. The silica was cleaned by soaking in a solution of 3: $198 \%$ sulphuric acid: hydrogen peroxide for $15-20$ minutes at $60^{\circ} \mathrm{C}$ followed by a rinse in Reverse Osmosis (RO) water, then blown dry with filtered air. The silica was coated with AZ 1400-31 photoresist (Shipley, Coventry, UK) by spinning-on at $4000 \mathrm{rpm}$ for 30 seconds followed by a soft bake at $90^{\circ} \mathrm{C}$ for $30 \mathrm{~min}$ utes. This gave a resist thickness of $1.8 \mu \mathrm{m}$. The resist was then patterned by exposing to ultra-violet light for $10 \mathrm{sec}-$ onds through a chrome mask patterned with the required grating pattern, using a mask aligner (HTG Inc, San Jose, CA, USA). The exposed resist was removed by immersing the sample in a solution of 1:1 Shipley developer: RO water for 65-75 seconds followed by a rinse in RO water and blown dry. The samples were etched in a Reactive Ion Etching Unit (Plasma Technology, Bristol, UK) in trifluoromethane gas. After etching the residual resist was removed, and all samples etched for an additional minute without protection to ensure uniform surface chemistry.

The step heights (depth of groove), which were $5 \mu \mathrm{m}$, were measured with a Dektak 23 stylus device sensitive to 0.5nm (Sloan Technology, Santa Barbara, CA, USA).

Structures were either used as supplied or by reusing structures after cleaning (for method see below).

Cleaning structures. After use structures were cleaned with the hydrogen peroxide/sulphuric acid reagent as described above, rinsed well with RO water and stored in $100 \%$ ethanol until shortly before use. They were then dried by evaporation in a sterile airflow.

\section{Cells}

Epitenal cells (Wojciak et al., 1995. Wojciak-Stothard et al., 1997 ) were grown from cultures isolated from rat flexor tendon and maintained for 80-100 passages in BHK 21 medium (Gibco/BRL Paisley, Scotland) (Minimal Essential Medium (MEM) plus 10\% foetal calf serum and tryptose-phosphate broth with an antibiotics/glutamine supplement. Suspensions of these cells were prepared by trypsinisation in 200 BAEE unit trypsin with $0.0005 \mathrm{M}$ EDTA in calcium and magnesium ion-free Hanks medium after an initial washing of the cells with $0.0005 \mathrm{M}$ EDTA in calcium and magnesium ion-free Hanks. The tryptic activ- ity was stopped by adding equal volumes of culture medium followed by further washing of the cells in this medium.

The cells were plated out on the microstructures or control surfaces in densities between $600-1000$ cells $/ \mathrm{cm}^{-2}$ in the same culture medium as for culture maintenance (controls) or in media modified by nitrate replacement of chloride (see below) or by addition of channel inhibitors, antibodies or antisense RNAs (see below for details). The cells were plated out at this low density so that the cells were well separated from each other. This avoids effects on cell spreading due to interactions between contacting cells. The cultures were then incubated at $37^{\circ} \mathrm{C}$ from 4 to 24 hours before fixation for morphometry. The 24 hour culture period was chosen to ensure that cells in control cultures could extend fully. Fixation was carried out with $4 \%$ formaldehyde in PBS (Phosphate-buffered saline).

\section{Low chloride media and chloride channel inhibitors}

The low chloride medium was prepared by replacing $\mathrm{Na}, \mathrm{K}$ and $\mathrm{Ca}$ chlorides with the corresponding nitrates at concentrations that maintained the iso-osmolarity of the medium. This type of medium was introduced by Hutter and Padsha (1959). The only chlorides present came from the serum and the tryptose phosphate broth and should correspond to ca $10 \%$ of the normal level (from serum and from the tryptose phosphate broth. The low chloride medium has a chloride molarity of about $0.01 \mathrm{M}$.

NPPB (5-Nitro-2- (3phenylpropylamino) benzoicacid) (Sigma, Poole, Dorset, UK) (Illek et al., 1992) was dissolved as a $10 \mathrm{mM}$ stock in dimethyl sulphoxide and used either at $50 \mu \mathrm{M}$ in culture medium or low chloride media. 4,4'-disothiocyanostilbene-2, 2' sulphonic acid (DIDS) (Sigma) was also used as a chloride channel blocker (Spiess et al., 1993) at 50, 100 and $150 \mathrm{nM}$ concentrations dissolved in the culture medium and diluted with the culture medium to the required concentrations. Chlorotoxin (Alamone Laboratories, Jerusalem, Israel), a chloride channel blocker (Du and Sorota, 1997), was used at $200 \mathrm{nM}$. Preliminary experiments established that these levels of the inhibitors produced no loss of cell viability in the time course ( 24 hours) of the experiments. Viability was judged by the fact that the cells resumed mitosis after removal of the inhibitor. The inhibitors were used at levels recommended in the literature quoted above.

\section{Antibody treatment}

An anti-ClC-3 antibody was obtained from Alamone Laboratories (Kawasaki et al., 1995). This is directed against an epitope found also in rat $\mathrm{ClC} 4 / 5$ proteins though not in other chloride channel proteins, according to the manufacturer's literature. It was applied at $125 \mu \mathrm{l}$ per $3 \mathrm{ml}$ against rat epitenon cells with 10 minutes pretreatment of the suspension before plating the cells onto structures with continued presence of the antibody in the system for the next 24 hours before fixation. Morphometry was then carried out. A control with Normal Rabbit serum was used.

\section{Internal $\mathrm{pH}$ of the cells}

Internal $\mathrm{pH}$ was measured with the fluorescent indicator BCECF-AM (Aceto-methoxy 2,7-bis- (2-carboxyethyl-5 
and 6) carboxylfluorescein) using the intensity of fluorescence at $530 \mathrm{~nm}$ as a measure of $\mathrm{pH}$ (Machen et al., 1998). Cells grown on flat or on groove ridge substrata were washed three times with serum-free medium, either control, low chloride and DIDS at $50 \mu \mathrm{M}$ and then after the addition of a fourth aliquot of the medium the indicator was added at $6 \mu \mathrm{M}$ and the cells incubated for 45 minutes at $37^{\circ} \mathrm{C}$. After this the cells were washed free of the indicator and the fluorescence intensity measured on images of individual cells using the NIH-Image program. Intensities are measured in arbitrary units of pixel grey level and the results expressed as integrated brightness values for each cell.

\section{Antisense experiments}

The antisense sequences were chosen by searching the BLAST database (Web reference 3 ) and choosing a 15merClC- 5 sequences in the case of sequence 006 from the first translated codon and in the case of sequence 007 from 18 nucleotides down-sequence. The sequences were recovered from the Swiss Protein database (Web reference 1) and are found in both $\mathrm{ClC}-5$ and $\mathrm{ClC}-6$ genes.

The following two 15-mer oligoribonuclcotide sequences based on $\mathrm{ClC}$ sequences were synthesised in phosphorothioate forms by Cruachem, (Glasgow, UK) with 2 phosphorothioate groups at the 5' end of each oligonucleotide: dUACCUGGAAGUUUUG termed 006, and dUACCUAAGCUGUUUUCC termed 007. In addition an arbitrarily chosen sequence unrelated to $\mathrm{ClC}$ genes was chosen as a control, dUACCGUAAGCUGUUUUC termed 008

These sequences were made up so that either 5 or 15 nanomole additions were made to the cultures, corresponding to 6 and 18 microgram respectively.

Penetration of the antisense was checked by the successful visualisation of fluorescein-labeled antisense 006 within the cells after they had been exposed to 10 microgram per $\mathrm{ml}$ of the antisense for 3 hours. After 20 hours the label was still within the cells that had by then failed to extend and spread.

Three types of experiment were carried out. In the first the cells were cultured in the presence of the antisense from the start of the culture. In the second the culture were grown in normal culture medium for 24 hours by which time the cells had spread and then exposed to one or other of the antisense RNAs to discover if the spread cell could be made to lose this reaction to topography. In the third the system was examined to discover if cells would recover their reaction to topography if the antisense was washed out and the cells cultured for a further 24 hours.

\section{Morphometry}

After fixation cells were stained using Coomassie Brilliant Blue R-250 (BDH-Merck) 2.5\% in methanol/ glacial acetic acid/ water (45\% 10\%, 45\% and destained appropriately in the same methanol-acetic acid reagent. Cells were photographed with a Nikon F-800 camera using T-max 100 film (Kodak) on a Leitz Diavert microscope with a X20 objective. The cells were measured along their longest axis parallel to the grooves and at their widest point at right angle to the groove axis. The greatest length of the cell was always within 5 degrees of the groove axis. Control cells on planar surfaces were measured along their greatest length and at 90 degrees to this. The resulting measurements were then processed using Statview 4.02.

\section{Cell movement}

Time lapse video recordings of cells growing on groove/ ridge structures were made with a phase-contrast microscope and a video camera at intervals of 1 second using a Sony 1025 video recorder. The videos were analysed by the Markov method described by Curtis and Wilkinson (1998) which extracts data on transition probabilities between motility and immotility and also the average speeds of the cells.

\section{Statistical methods}

When groups of experiments containing more than two groups were compared ANOVA methods were used. Variance ratios (F test) were calculated to test whether the data sets came from a single population. Comparisons of individual pairs of experiments from these data sets were performed with the methods described by Snedecor and Cochran (1980) using the t-test described by them for making these tests against the background of the total data set (a type of Bonferroni correction). Comparisons of data groups in experiments in which there was only a pair of sets were compared by the t-test modified so that unequal set sizes and different variances could be taken into account. All data sets met tests that the data was normally distributed.

\section{Results}

\section{Effects of chloride channel inhibition on cell morphology on ridge/groove substrata.}

When chloride in the medium had been replaced with nitrate the extension of cells and width on the 5- $\mu \mathrm{m}$ grooves was significantly reduced (Fig. 1, Table 1). The cells appeared to be increased in thickness in the $\mathrm{z}$ axis. In controls most of the cytoplasm of each cell is confined to a single groove or ridge but the cell usually overlaps a groove or ridge on either side in the region of the nucleus. The difference in extension of the cells appears within thirty minutes of plating out. Control cells continued developing their extension along the grooves for up to 24 hours but those in low chloride media ceased to extend within a few hours and such extension as they made proceeded more slowly.

The three inhibitors NPPB, DIDS and Chlorotoxin reduced cell spreading (length) significantly on $5 \mu \mathrm{m}$ topography and on $10 \mu \mathrm{m}$ topography (Fig. 1, Table 1). Significant increase in width was also seen for these inhibitors (Fig. 2, Table 1), except for NPPB in normal medium. The effects on cell shape (length and greatest width) are shown in Table 1 with images of the cells in Figure $3 a$ and $b$.

The overall effect on cell morphology is illustrated by Table 2 where the ratio between greatest length and width is tabulated. Cells on the $5 \mu \mathrm{m}$ topography were ten times as long as wide but this was reduced to two times with the more active inhibitor. This difference appeared clearly within a few hours.

The increase in width in the presence of inhibitors (see 
Table 1. Statistical analysis of data on effects of inhibitors

\section{Treatment}

\section{$5 \mu \mathrm{m}$ wide grooves/ridge}

Control

Low chloride

NPPB

NPPB and low chloride

DIDS

Chlorotoxin

\section{$10 \mu \mathrm{m}$ wide groove/ridge}

Control

Low chloride

NPPB

NPPB and low chloride

DIDS

Chlorotoxin

\section{$5 \mu \mathrm{m}$ wide groove/ridge}

Control

Low chloride

NPPB

NPPB and low chloride

DIDS

Chlorotoxin

\section{$10 \mu \mathrm{m}$ wide groove/ridge}

$\begin{array}{ll}\text { Control } & 9.3 \\ \text { Low chloride } & 10.8 \\ \text { NPPB } & 10.2 \\ \text { NPPB and low chloride } & 14.8 \\ \text { DIDS } & 22.8 \\ \text { Chlorotoxin } & 12.8\end{array}$

F value

34.1

$\mathrm{P}<0.005$

Df 3,321

38.8

88.3

76.6

60.5

56.9

40.6

52.2
88.9

$\mathrm{P}, 3,642$

110.9

$\mathrm{P}<0.005$

Df 3,554
Pairwise comparison (with control)

\begin{tabular}{ll}
\multicolumn{1}{r}{ NA } & \\
$\mathrm{t}=13.2$ & $\mathrm{P}<0.01$ \\
$\mathrm{t}=8.1$ & $\mathrm{P}<0.01$ \\
$\mathrm{t}=24.6$ & $\mathrm{P}<0.001$ \\
$\mathrm{t}=22.3$ & $\mathrm{P}<0.01$ \\
$\mathrm{t}=21.9$ & $\mathrm{P}<0.01$
\end{tabular}

$\begin{array}{ll}\quad \text { NA } & \\ \mathrm{t}=1.29 & \mathrm{NS} \\ \mathrm{t}=3.07 & \mathrm{P}<0.01 \\ \mathrm{t}=3.49 & \mathrm{P}<0.01 \\ \mathrm{t}=6.31 & \mathrm{P}<0.01 \\ \mathrm{t}=3.99 & \mathrm{P}<0.01\end{array}$

2.1

NS
NA

$\mathrm{t}=2.9, \mathrm{df}=61 \quad \mathrm{P}<0.01$

$\mathrm{t}=5.3, \mathrm{df}=32 \quad \mathrm{P}<0.01$

$\mathrm{t}=5.4, \mathrm{df}=32 \quad \mathrm{P}<0.01$

$\mathrm{t}=10.2, \mathrm{df}=90 \quad \mathrm{P}<0.01$

$\mathrm{t}=4.2, \mathrm{df}=381 \quad \mathrm{P}<0.01$
Fig 2) is to be viewed as a reduction in reaction to topography because the cell becomes less oriented (in other words more like cells on a planar surface). There appears also to be a reduction in cell adhesion because fewer cells were found attached. There was no apparent loss of cell viability.

These and other results are compared with behaviour on planar surfaces in Table 3 .

Cells grown on planar surfaces were exposed to the same concentrations of the same set of inhibitors. Table 3 shows, that with the exception of DIDS and chlorotoxin, there are no significant differences at $\mathrm{P}<0.01$ in cell length (greatest axis) or cell width minor axis) between controls and those cultures treated with the various inhibitors. The same statement applies to the minor axis of the cells (cell width). These dimensions of the cells were significantly different from those cells on grooves treated with the same inhibitors. In other words the response of cells growing on planar surfaces to these inhibitors was slight compared with the situation on grooves.

Cell movement was relatively little affected by $300 \mu \mathrm{M}$ chlorotoxin. Results are shown in Table 4. The methods used and results obtained (for control cells) are identical with those and even the cell type is identical with those described by Curtis et al. (1995). The movement is at times strongly polarised in one or the opposite direction along the grooves - never across them.

\section{Antibody against chloride channels}

Measurements on the length of the cell extension along the structures were made. The anti-ClC-3 antibody significantly reduced cell length as compared with controls (Table 4). Subsidiary experiments showed that this antibody binds specifically to the cells and can be visualised with a fluorescent secondary antibody.

\section{Does use of chloride channel inhibitors or low chloride medium change cell $\mathbf{p H}$ ?}

The results of the experiments are shown in Figure 4. The results suggest that the low chloride treatment combined with the DIDS treatment does not lower internal cell $\mathrm{pH}$ because the intensities are slightly higher in the treated cells. $\mathrm{pH}$ reduction would be signalled by a loss in fluorescence intensity of approx $90 \%$ per $\mathrm{pH}$ unit. 


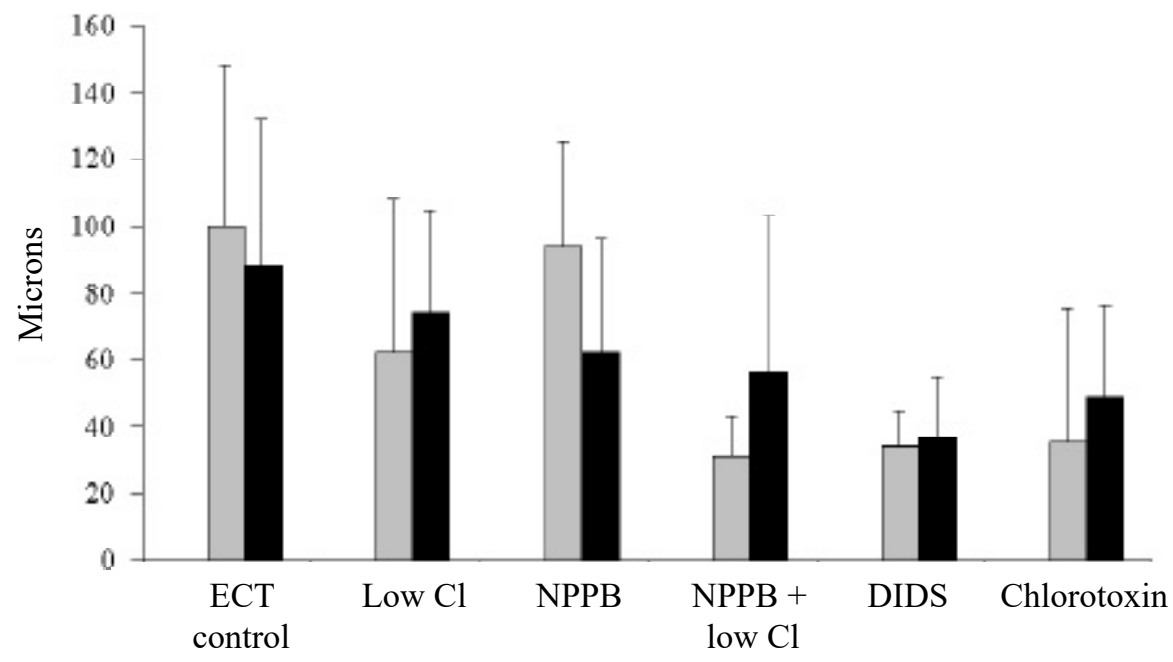

Figure 1. Effects of various reagents affecting chloride channels on cell length on 5 and $10 \mu \mathrm{m}$ wide grooves. Error bars 1 standard deviation. ANOVA analysis shows that the data sets for $5 \mu \mathrm{m}$ wide grooves a) cell length, b) cell greatest width and for $10 \mu \mathrm{m}$ wide grooves c) cell length and d) cell greatest width yield, respectively, $\mathrm{F}$ values of a) 34.1, b) 110.9, c) 88.9, and d) 2.1. Details of statistical tests in Table 1. Comparisons with effects on planar surfaces in Table 3. Grey bars for data on cells grown on $5 \mu \mathrm{m}$ wide grooves, black bars for $10 \mu \mathrm{m}$ wide grooves.

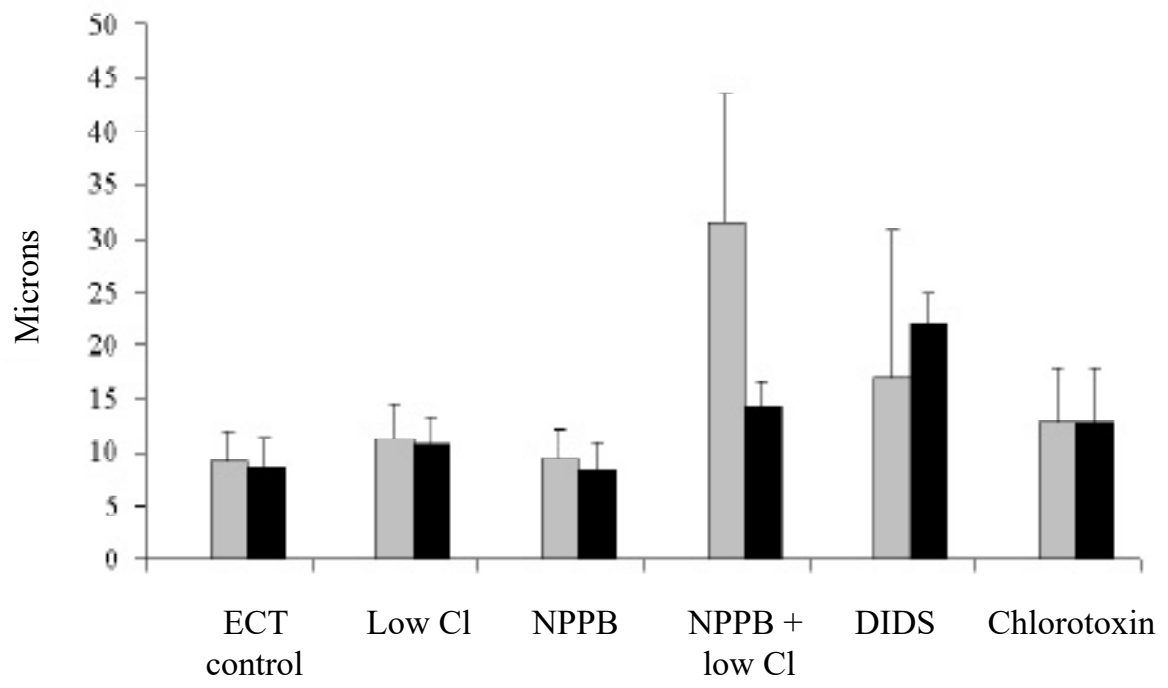

Figure 2. Effects on cell greatest width (breadth) on 5 and $10 \mu \mathrm{m}$ wide grooves of various reagents affecting chloride channels, Error bars 1 standard deviation. Details of statistical tests in Table 1. Comparisons with effects on planar surfaces in Table 3. Grey bars for data on cells grown on $5 \mu \mathrm{m}$ wide grooves, black bars for $10 \mu \mathrm{m}$ wide grooves.

\section{Antisense RNA to chloride channel ClC-5 or CIC-6}

Though ClC-5 was cloned as a human kidney chloride channel it is a member of a very homogenous family and shows high homology $(>80 \%)$ with the gene for a mechanosensitive channel in Caenorhabditis (Web reference. 1, Jentsch and Gunther, 1997). Two sequences were chosen which are unique to the $\mathrm{ClC}-5 / 6$ gene sequences. The sequences used are listed in Materials and Methods. Suspensions of epitenon cells were placed on silica structures with grooves 5 or $10 \mu \mathrm{m}$ width and pitches of 10 or $20 \mu \mathrm{m}$ at densities of $2 \times 10^{4}$ cells per structure. $25 \mathrm{~mm}$ diameter cloning rings were attached to the $25 \times 25 \mathrm{~mm}$ structures so that volumes of culture fluid were kept low. After the cells had settled (3 hours) minimal volumes of Antisense RNA, sequences A or B or the non-chloride chan- nel sequence $\mathrm{C}$ were added to the cultures. These reagents were added at 5 or 15 nanomoles in volumes of 5 or $15 \mu$. to culture fluid totaling $2 \mathrm{ml}$ per structure. Controls were carried out with a similar volume of fresh ECT medium added. In a second series of experiments the cultures were grown for 24 hours in normal ECT medium which was then replaced with same antisense solutions for 24 hours further culture. After 24 hours in the antisense solutions the cultures were fixed, stained and morphometry carried out. This experiment tests whether cells that have already reacted to topography can lose that reaction in the presence of the appropriate antisense

In the third set of experiments, which examined recovery from the presence of antisense RNA, the cultures were treated with antisense for 24 hours as the first set of 
Table 2. Length/width ratios

$\begin{array}{lll}\text { Treatment } & \mathbf{5 \mu m} & \mathbf{1 0} \boldsymbol{\mu m} \\ \text { Control } & 10.4 & 9.52 \\ \text { Low chloride } & 9.44 & 7.07 \\ \text { NPPB } & 7.81 & 5.94 \\ \text { NPPB Low chloride } & 2.2 & 4.66 \\ \text { DIDS } & 2.01 & 1.70 \\ \text { Chlorotoxin } & 3.0 & 4.08\end{array}$

Table 3. Effects on cell spreading of various chloride channel inhibitors using planar surfaces

\begin{tabular}{|c|c|c|c|c|c|c|c|c|}
\hline Medium & Major axis & & & t value & Minor axis & & & t value \\
\hline & Mean & s.d. & cf. ECT & & Mean & s.d. & cf. ECT & \\
\hline ECT (control) & 76.0 & 45.9 & & & 30.0 & 18.0 & & \\
\hline Low chloride & 65.1 & 37.7 & 1.3 & NS & 19.0 & 11.0 & 2.7 & $\mathrm{P}<0.02$ \\
\hline NPPB medium & 66.1 & 39.3 & 1.2 & NS & 28.2 & 16.1 & 0.3 & NS \\
\hline DIDS (50 mM) & 51.9 & 30.1 & 3.2 & $\mathrm{P}<0.01$ & 25.0 & 14.2 & 1.0 & NS \\
\hline Chlorotoxin & 30.3 & 14.7 & 6.8 & $\mathrm{P}<0.01$ & 16.9 & 6.0 & 3.1 & $\mathrm{P}<0.01$ \\
\hline
\end{tabular}

Sample sizes all exceeded 20 cells

Table 4. Effect of anti-ClC-3 antibody on epitenon cell length on grooved surfaces

$\begin{array}{lllcc}\text { Type } & \text { Mean length } & \text { St Dev } & \text { n } & \text { t-value } \\ \text { Controls } 5 \mu \mathrm{m} \text { groove } & 118.3 & 48.8 & 12 & 4.0 \quad \mathrm{P}<0.001 \mathrm{df}=25 \\ \text { Exptl. } 5 \mu \mathrm{m} \text { groove } & 75.2 & 31.2 & 15 & \\ \text { Control } 10 \mu \mathrm{m} \text { groove } & 113.6 & 37.9 & 20 & 2.9 \mathrm{P}<0.01 \mathrm{df}=41 \\ \text { Exptl. } 10 \mu \mathrm{m} \text { groove } & 64.9 & 40.6 & 25 & \end{array}$

Table 5. Internal $\mathrm{pH}$ of cells.

Fluorescence yields as average grey levels per pixel on cells

$\begin{array}{llll}\text { Controls } & 90 & \text { sd } 11.3 & \mathrm{n}=6 \\ \text { Low chloride with DIDS } & 101 & \text { sd } 14.5 & \mathrm{n}=8\end{array}$

See Figure 4

Table 6. Values of $t$ in tests of comparison between Controls and Antisenses on cell length and width.

\begin{tabular}{|c|c|c|c|c|c|c|}
\hline \multicolumn{3}{|c|}{ Length after 24 hours exposure to antisense : $t$ compared with Control } & \multicolumn{2}{|c|}{ 007(Reagent B) } & & \\
\hline $\mathrm{t}$ value $(5 \mu \mathrm{m}$ grooves $)$ & 14.5 & $\mathrm{P}<0.01$ & 1.009 & NS & 1.22 & NS \\
\hline t value $(10 \mu \mathrm{m}$ grooves $)$ & 4.52 & $\mathrm{P}<0.01$ & 0.79 & NS & 1.60 & NS \\
\hline \multicolumn{7}{|c|}{ Length after 24 hours treatment following 24 hours to allow cells to spread } \\
\hline $\mathrm{t}$ value $(5 \mu \mathrm{m}$ grooves $)$ & 11.24 & $\mathrm{P}<0.001$ & 3.36 & $\mathrm{P}<0.01$ & 1.2 & NS \\
\hline t value $(10 \mu \mathrm{m}$ grooves & 4.51 & $\mathrm{P}<0.01$ & 0.79 & NS & 1.6 & NS \\
\hline \multicolumn{7}{|c|}{ Length after 24 exposure followed by 24 hours recovery. Value at 24 hrs compared with controls } \\
\hline $\mathrm{t}$ value $(5 \mu \mathrm{m}$ grooves before recovery) & 8.43 & $\mathrm{P}<0.01$ & 4.05 & $\mathrm{P}<0.01$ & 3.0 & $\mathrm{P}<0.01$ \\
\hline $\mathrm{t}$ value $(5 \mu \mathrm{m}$ grooves after recovery) & & NS & 4.6 & $\mathrm{P}<0.01$ & & NS \\
\hline $\mathrm{t}$ value $(10 \mu \mathrm{m}$ before recovery) & 3.26 & $\mathrm{P}<0.01$ & 6.2 & $\mathrm{P}<0.01$ & & NS \\
\hline $\mathrm{t}$ value $(10 \mu \mathrm{m}$ after recovery & & NS & 4.4 & $\mathrm{P}<0.01$ & & NS \\
\hline
\end{tabular}

Df $=26$ in every comparison. 


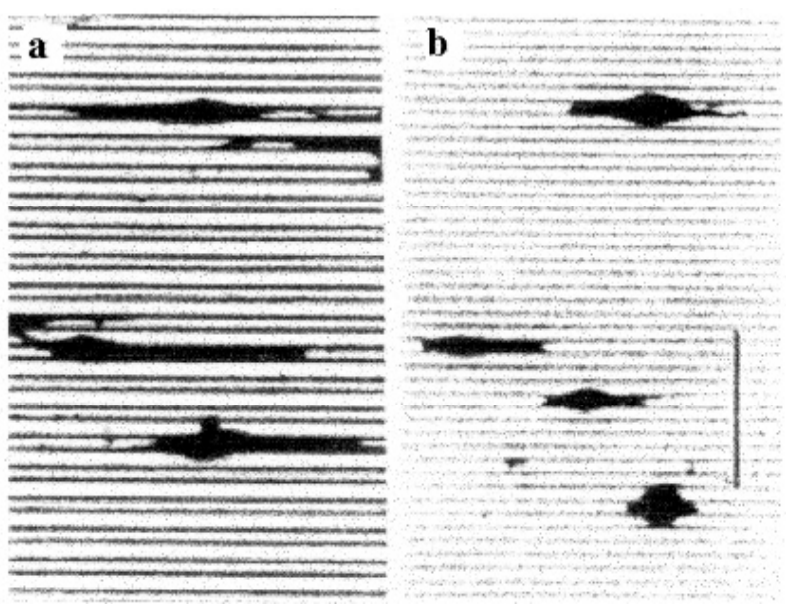

Figure 3. The effects of low chloride media on Epitenon cell spreading on $5 \mu \mathrm{m}$ groove topography. This medium causes a reduction in the extended length of the cell. Coomassie Blue stained cultures: (a) ECT control, (b) Low chloride medium Scale Bar $50 \mu \mathrm{m}$. Note that diffraction effects due to the topography make the grooves appear differently in different images when slight differences in focus have been used.
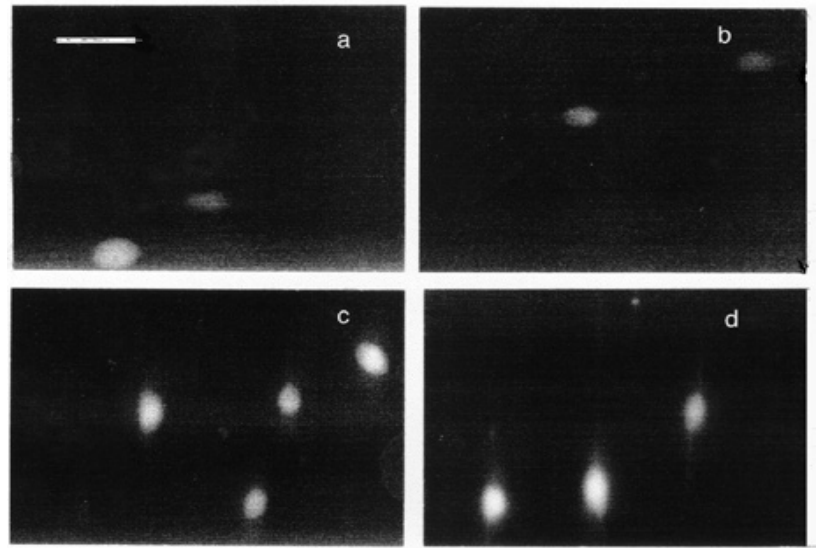

- $\mathrm{pH} 6.0$

- pH 5.0

Figure 4. Fluorescence detection of internal $\mathrm{pH}$ using acetomethoxy 2,7-bis- (2-carboxyethyl-5 and 6) carboxylfluorescein. a and b Controls ; c and d, Low chloride with $50 \mu \mathrm{M}$ DIDS. Scale Bar $20 \mu \mathrm{m}$.
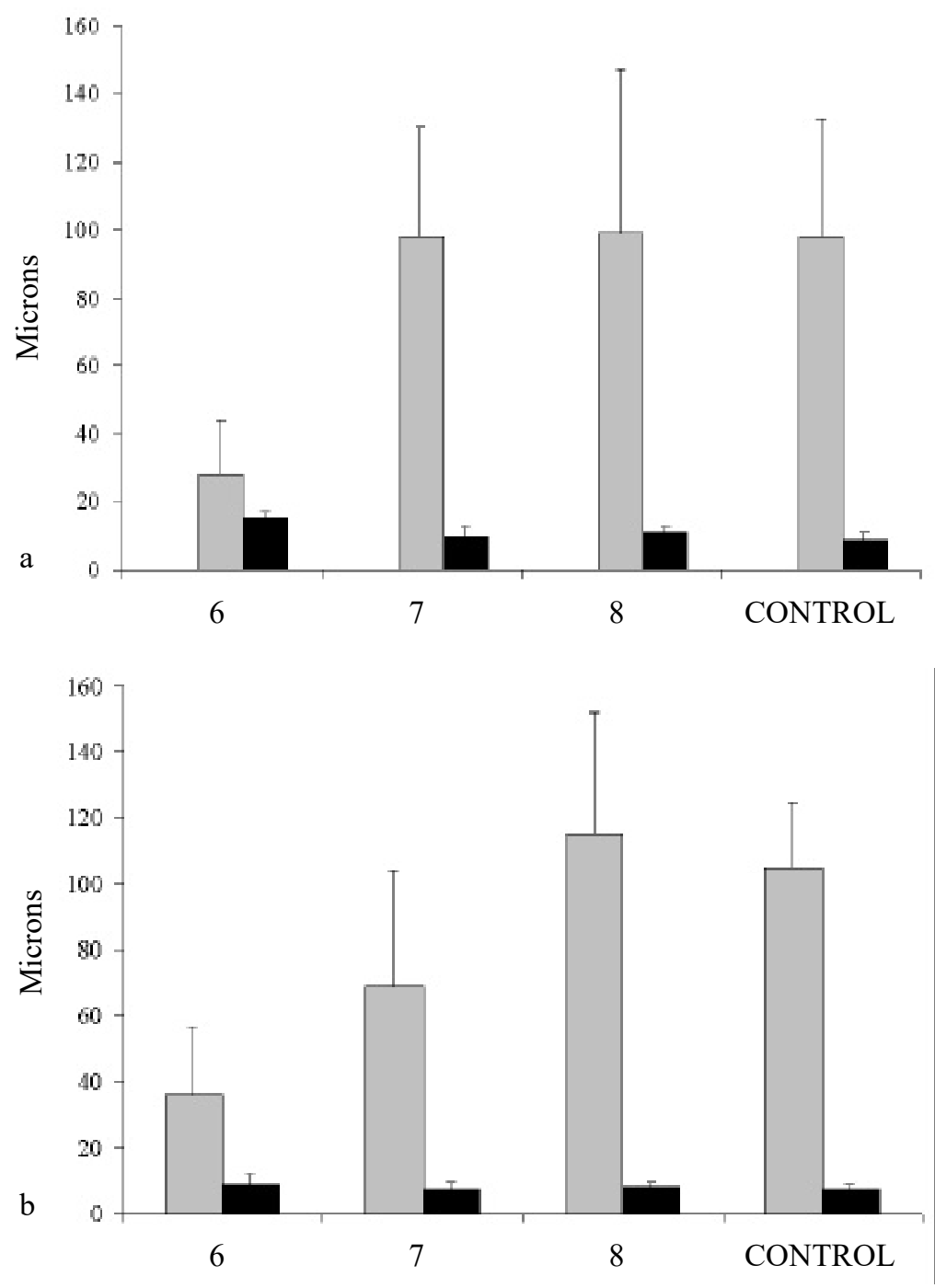

Figure 5. Antisense treatments. Cell lengths (grey bars) and greatest widths (black bars) on a) $5 \mu \mathrm{m}$ wide grooves, b) on $10 \mu \mathrm{m}$ wide grooves, after 24 hours treatment. Error bars 1 standard deviation. Labels ' 6 '.' 7', and ' 8 ' refer to Antisense 006, 007 and 008 . 

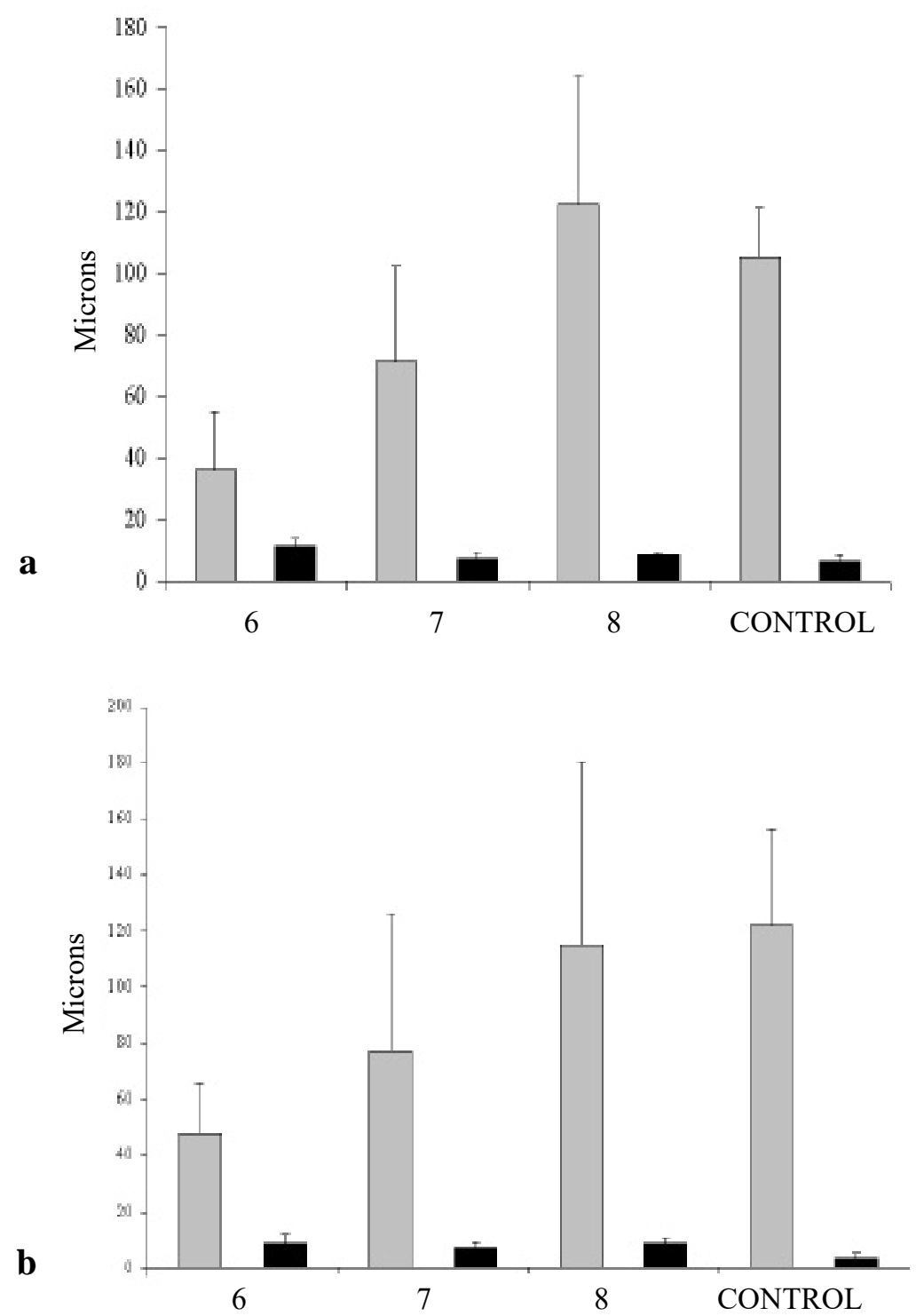

Figure 6. Antisense 24 hours delay in application. Does the antisense reverse normal extension along grooves? Cell lengths (grey bars) and greatest widths (black bars). Fig a) Cell lengths and greatest widths on $5 \mu \mathrm{m}$ wide grooves, Fig. b) on $10 \mu \mathrm{m}$ wide grooves after 24 hours treatment ( 48 hours total culture time). Error bars 1 standard deviation. Labels ' 6 '.'7', and ' 8 ' refer to Antisense 006, 007 and 008.

experiments then the medium was removed and replaced with fresh control medium three times and the cultures grown for a further 24 hours before fixation.

Results are shown in Table 6 and appearances of cells in Figures 5- 8.

Both antisense sequences 006 and 007 significantly prevent cell extension (longer and narrower cells) on both 5 and $10 \mu \mathrm{m}$ wide grooves, compared with experiments with control nucleotide sequences, but as with experiments on low chloride, effects on length (extension) are significant while those on width are not significant (see Table 6 and Figures 5-8 for details of data and statistical tests). When the antisense treatment was delayed for 24 hours so that the cells had reacted to the structures by extension before addition of antisense the antisense treatment with A or B sequences caused cell retraction to a considerable extent. Antisense $\mathrm{C}$ had no effect (Fig. 6, Table 6). Removal of the antisense solutions in the third experiment allowed the cells to respread over a further 24 hour period(Fig. 7, Table 6). Clearly the cells were not greatly affected in other respects since they recovered well from the antisense treatment.

Only Antisense 006 had a significant effect on both 5 and $10 \mu$ wide grooves. When Antisense was applied after cells had reacted Antisense 006 had a significant effect as did the closely related 007 . Antisense 008 (chosen as a control) has no effect on cell length when compared with controls in the first two experiments. The recovery experiment has the interesting feature that not only do the cells recover their extension but actually overshoot for Antisense 007. The results on cell length before recovery parallel those found in the first experiment. 


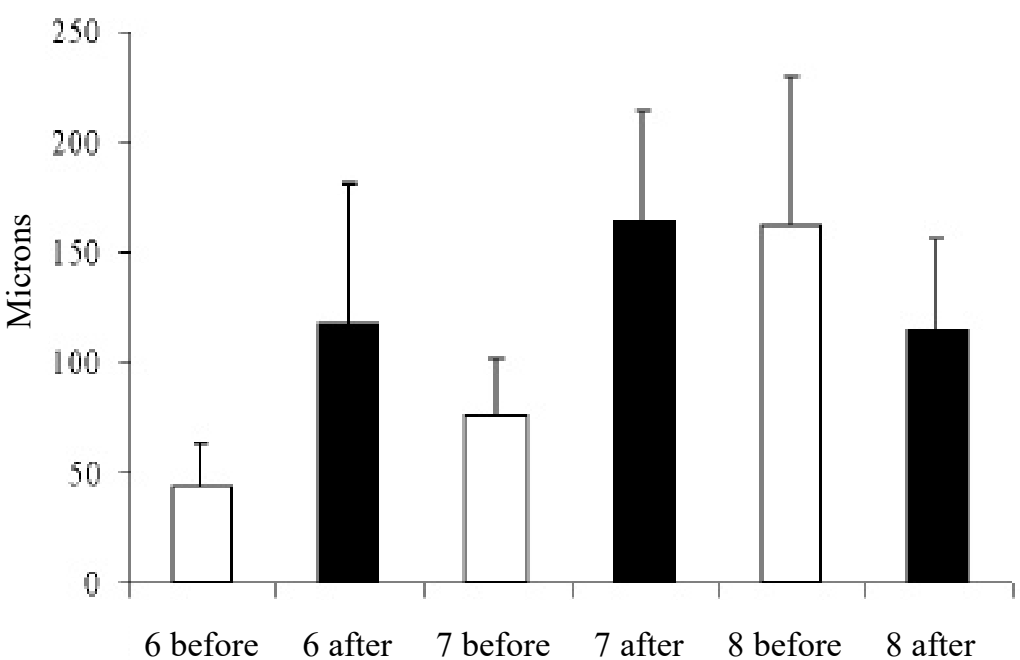

$\mathrm{b}$

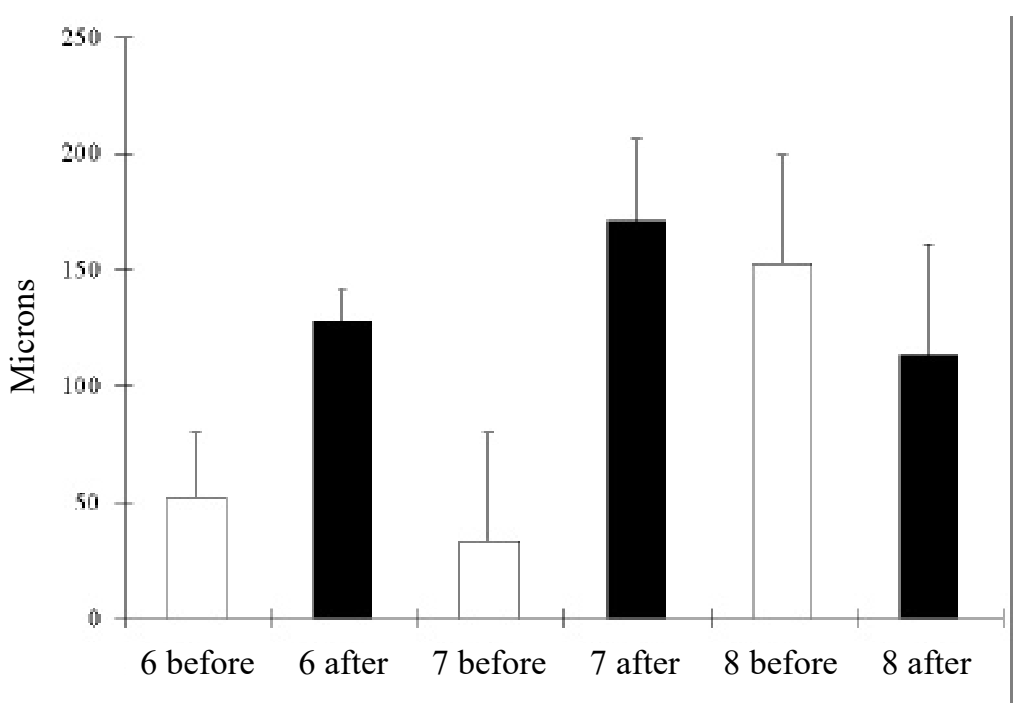

Figure 7. Recovery from Antisense treatment. Fig a) Cell lengths on $5 \mu \mathrm{m}$ wide grooves, Fig. b) on $10 \mu \mathrm{m}$ wide grooves after 24 hours treatment. White bars, before treatment, Black bars, 24 hours after treatment started. Error bars 1 standard deviation.Labels '6'.'7', and '8' refer to Antisense 006, 007 and 008.

\section{Discussion}

Though it has been widely held that calcium channels are involved in the reception of mechanical tension by cells there is much evidence that chloride channels are involved (Web reference 1). Unlike calcium channels some chloride channel, at least, have the mechanically correct structure of paired channels capable of three levels of response and an asymmetric structure (Ludewig et al., 1996,1997). This is the structure that would be expected of a stretch receptor because such a structure could make $\mathrm{x}$, y comparisons. This paper presents a range of types of evidence that chloride channels are involved in the reactions of cells to topographical features. We do not present direct evidence of the opening or closing of chloride channels under tension, self-generate or applied, because the time scale of the channel openings and closings will be very much shorter than the time scale of the reaction to topography. The assay we have used for the reaction is an end-point reaction so that differences between experimental treatments are maximal, but reactions to topography start in about five minutes (Wojciak-Stothard et al., 1995a, 1996).

Though cells have been shown to develop mechanical tension in the direction of the long axis of the cells by Harrris (1982) it was not clear whether they developed appreciable tension across the width of the cell. More recent results suggest that tensions are developed around all the periphery of a cell pulling the cell towards its centre. In other words the contractions seem to be generated around most if not all of the periphery of these cells (Pelham and Wang, 1999; Raucher and Sheetz, 2000), leading to the conclusion that cell spreading and lamellipodial extension rate are regulated by membrane tension. Thus it is reasonable to investigate whether stretch-detecting systems such as chloride channels are involved in these reactions.

The results of the experiments we report are all consistent with the hypothesis that an active chloride channel system is required for the reaction of cells with topography. The low chloride experiment, the use of chloride channel inhibitors including an antibody directed against such channel proteins and the antisense experiments all suggest that cells treated in these various manners spread on the 

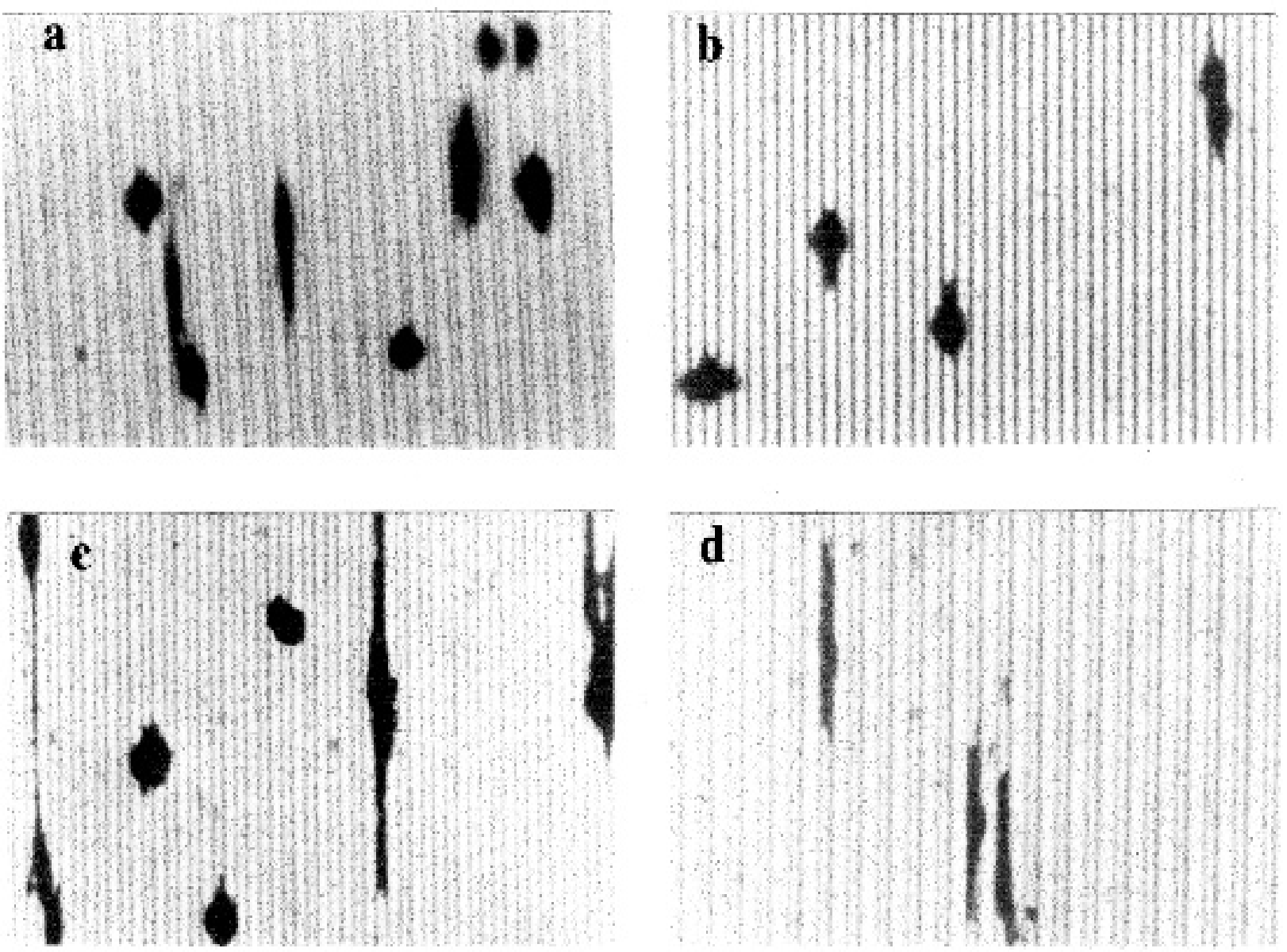

Figure 8. Effects of Anti-chloride channel 5/6 Antisense (006) on Epitenon cell morphology. On $5 \mu \mathrm{m}$ groove topography 24 hours culture. Coomassie Blue stained cultures. Compare with Fig.1 which shows untreated controls. Random antisense (Image a), Antisense (006) 1 nanomole per culture (Image b). Antisense A 15 nanomole per culture (Image c). Random oligoribonucleotide, 15 nanomole per culture Antisense 007, 1 nanomole per culture (Image d) and 15 nanomole per culture (Image e) on Epitenon cells. Scale Bar $50 \mu \mathrm{m}$.

substrate on being plated out, but that extension is reduced along the length of the grooves but slightly increased at right angles to the grooves. In other words the topographic reaction of extending along grooves or ridges is reduced by these treatments though the spreading across the grooves is increased. These two opposite changes are consistent with the idea that the treatments have reduced the reactions of cells to their own mechanical tensions. The typical contact guidance type of reaction to groove ridge topography has been impaired by these treatments though motility of the cells is little affected. The evidence for chloride channel involvement we present is consistent with the hypothesis that stretch reception is an early event in the reaction of cells to topography. It should be noted that as channel inhibition is achieved the cells approach the morphology shown on planar surface.

It is difficult to form a definite conclusion as to whether the reduction in spreading along the groove is precisely balanced by the increase across the grooves because we do not have thickness measurements on the various protrusions of the cell but it seems likely that there is at least a partial compensation of one by the other.

Our results suggest that the role of chloride channels in the reaction to topography is less marked on the $10 \mu \mathrm{m}$ grooves compared with the $5 \mu \mathrm{m}$ grooves. However, the controls (Fig. 1) also show that the reaction of the epitenon cells to the wider topography is less marked than to the $5 \mu \mathrm{m}$ wide grooves.

It can of course be argued that the channel inhibitors are not highly specific and there certainly are other cellular effects of these inhibitors (Illek et al., 1992; Spiess et al., 1993; Du and Sorota, 1997), but the consistency with the three other types of evidence suggests that chloride channels are involved.

It is noteworthy that the effects of low chloride can enhance the effects of the inhibitors. This is consistent with the possibility that we are not using the most effective concentrations of these inhibitors but also adds to the strength of the hypothesis that chloride channels and chloride transport are involved in the reactions.

The close sequence similarities between $\mathrm{ClC}-3, \mathrm{ClC}-4$ and $\mathrm{ClC}-5$ in rats mean that we have not been able to make a clear distinction between which of these channel types is responsible for the effects we report. This applies both to the antisenses and to the specificity of the antibody. This group of channel types appears to have associations with 
endosomes and vesicle traffic including synaptic vesicles in nerve cells (Kornak et al., 2001).

Rajnicek and McCaig (1997) examining the topographical reactions of hippocampal neurites to groove ridge topography concluded that there was no clear cytoskeletal involvement in this reaction. They obtained evidence but that protein kinase $\mathrm{C}$ and calcium ion changes were involved. If the reactions of cells to externally applied mechanical forces (e.g., Banes et al., 1995) is similar in nature to the reaction to topography we are faced with the possibilities that different cell types differ in their mechanism of reaction or that despite the apparently similar mechanical situation the systems are not alike.

The other explanations of the reactions of cells to topography (Curtis and Varde, 1964; Dunn and Heath, 1976; Ohara and Buck, 1979; Chehroudi and Brunette, 1995) are either non-specific about the reactive elements in the cells or suggest the involvement of the cytoskeleton. It is clear from the results of Wojciak-Stothard et al. (1995a) that there are changes in the cytoskeleton as cells react and these do appear within a few minutes of setting onto the substratum.

The involvement of chloride channels in the stretching reactions of cells to volume changes caused osmotically has been widely reported and reviewed by Ludewig et al. $(1996,1997)$ and by Du and Sorotta (1997). The mechanical stretching of cells by external forces has produced evidence that calcium ion kinetics are involved in those reactions (Rajnicek and McCaig, 1997). Much of the evidence in those papers comes from the use of gadolinium chloride as an inhibitor - since this is a trivalent ion its effects are likely to be non-specific. On the other hand some chloride channels can be activated by calcium. The possibility that low chloride or chloride inhibitors cause reductions in internal $\mathrm{pH}$ which might reflect on actin function (Vexler et $a l ., 1996)$ is discounted by our experimental results on internal $\mathrm{pH}$.

Chloride channel involvement in cell adhesion has been proposed by Martin et al. (1996). These workers found that blocking chloride channels reduced adhesion. A similar result was found by Eible et al. (1997). Was this because the cells would not spread adequately to resist medium movement pulling the cells off or is there a parallel involvement of adhesion and stretch reception? It might be argued that reduction in adhesion is the primary effect of chloride channel imhibition and that effects on cell shape are downstream effects. However, despite using an endpoint analysis in measuring the effects on cell shape it is clear that effects on cell extension start very soon after the cells settle on the substratum. In earlier work Wojciak et al. (1995) showed that cell orientation and cytoskeletal orientation to topography is evident only 5 minutes after plating out.

\section{Acknowledgements}

We thank W. Monaghan of the Department of Electronics and Electrical Engineering, University of Glasgow for providing microfabricated structures, Dr Mathis Riehle for advice and training in the use of image analysis systems, Tong-Tong Li for data on the effects of random oligoribonucleotides and Professor Chris Wilkinson for encouragement and valuable discussion. We are also especially grateful to Professor Otto Hutter for pointing out to us the experimental value of replacing chloride by nitrate. The work was supported by EPSRC grant GR//L/83998.

\section{References}

Banes AJ, Tsuzaki M, Yamamoto JY, Fischer T, Brigman B, Brown T, Miller L. (1995). Mechanoreception at the cellular level: The detection, interpretation, and diversity of response to mechanical signals. Biochem Cell Biol 73: 349-365.

Bassett Douglas E Jr, Boguski MS, Spencer F, Reeves R, Goebl G, Hieter P (1992) Comparative genomics, genome cross-referencing and XREFdb Trends in Genetics 11: 372-373.

Britland S, Perridge C, Denyer M, Morgan, H, Curtis A, Wilkinson C (1996) Morphogenetic guidance cues can interact synergistically and hierarchically in steering nerve cell growth. Exp Biol Online - EBO. 1:2.

Chehroudi B, Brunette DM (1995) Effects of surface topography on cell behavior. In: Encyclopedic Handbook of Biomaterials and Bioengineering. Part S. Materials. Donald DJT, Wise L, Altobelli DE, Yaszenski Gresser JD, Schwartz ER (eds.). Marcel Dekker, New York. 1: 813842.

Clark P, Connolly P, Curtis ASG, Dow JAT, Wilkinson CDW (1987) Topographical control of cell behaviour. I. Simple step cues. Development 99: 439-448.

Clark P, Connolly P, Curtis ASG, Dow JAT, Wilkinson CDW (1990) Topographical control of cell behaviour II. Multiple grooved substrata. Development 108: 635-644.

Curtis ASG, Varde M (1964) Control of cell behaviour - topological factors. J Natl Cancer Inst 33: 15-26.

Curtis ASG, Wilkinson C (1998). Topographical control of cells. Biomaterials 18: 1573-1583.

Du XT, Sorota, S (1997) Cardiac swelling-induced chloride curve. Am J Physiol 272: H1904-H1916.

Dunn GA, Heath JP (1976). A new hypothesis of contact guidance in tissue cells. Exp Cell Res 101: 1-14.

Eible RC, Widom J, Gruber AD, Abdel-Ghany M, Levine R, Goodwin A, Cheng HC, Pauli BU (1997). Cloning and characterization of lung-endothelial cell adhesion molecule-1 suggest it is an endothelial chloride channel. J Biol Chem 272:27853-27861.

Harris AK (1982) Traction, and its relations to contraction in tissue cell locomotion. In: Cell Behaviour. A Tribute to Michael Abercrombie. Bellairs R, Curtis A, Dunn G (eds). Cambridge University Press, Cambridge. pp. 109134.

Hutter OF, Padsha SM (1959) Effect of nitrate and other anions on the membrane resistance of frog skeletal muscle. J Physiol 146: 117-134.

Illek B, Fischer H, Kreusel KM Hegel U, Clauss W (1992) Volume-sensitive basolateral $\mathrm{K}^{+}$channels in HT29/B6 cells. Block by lidocaine, quinidine, NPPB and $\mathrm{Ba}^{2+}$. Am J Physiol 263:C674-C683.

Jentsch TJ, Gunther W (1997) Chloride channels: An emerging molecular picture. Bioessays. 19: 117-126.

Kawasaki M, Suzuki M, Uchida S, Sasaki S, Marumo 
F (1995) Stable and functional expression of the ClC-3 chloride channel in somatic cell lines. Neuron 14: 285 1291.

Kornak , Kasper D Bost MR, Kaiser E, Schweizer M, Schulz A, Friedrich W, Delling G, Jentsch TJ (2001) Loss of the $\mathrm{ClC}-7$ chloride channel leads to osteopetrosis in mice and man. Cell 104: 205-215.

Ludewig U, Pusch M, Jentsch TJ (1996) Two physically distinct pores in the dimeric CIC-O chloride channel. Nature 383: 340-343.

Ludewig U, Pusch M, Jentsch, TJ (1997) Each subunit forms an independent pore in the dimeric CIC-0 chloride channel. Biophys J 72: MAMC6-MAMC6.

Machen T, Teter K, Chandy G, Giorgi I, Wu M, Lin S, Quinones B, Llopis J, Tsien R, Moore HP (1998) Measuring $\mathrm{pH}$ regulation in cellular organelles. FASEB J 12: 1900 (abstract).

Martin D K, Boneham GC, Pirie BL, Collin HB, Campbell TJ (1996) Chloride ion channels are associated with adherence of lymphatic endothelial cells. Microvascular Res 52: 200-209.

Middleton RE, Pheasant DJ, Miller C. (1996) Homodimeric architecture of a ClC-type chloride ion channel. Nature 383: 337-340.

Ohara PT, Buck RC (1979) Contact guidance in vitro: a light, transmission and scanning electron microscope study. Exp Cell Res 121: 235-249.

Pelham RJ, Wang Y-L (1999) High resolution detection of mechanical forces exerted by locomoting fibroblasts on the substrate. Mol Biol Cell 10: 435-445.

Rajnicek AM, McCaig CD (1997) Guidance of CNS growth cones by substratum grooves and ridges : effects of inhibitors of the cytoskeleton, calcium channels and signal transduction pathways. J.Cell Sci 110: 2915-2914.

Raucher D, Sheetz MP (2000). Cell spreading and lamellipodial extension rate is regulated by membrane tension. J Cell Biol 148: 127-136.

Snedecor GW, Cochran WG (1980) Statistical Methods. 7th Edition. Pp xvi + 507. Iowa State University Press, Ames.

Spiess I,Wang JN, Jeinz R, Zimmermann U (1993) Characterization of the chloride carrier in the plasmalemma of the alga Valonia utricularis - The inhibition by 4.4"diisothiocyanatostilbene 2.2' disulfonic acid. Biochim Biophys Acta 1149: 93-101.

Vexler ZS, Symons S, Barber DL (1996) Activation of $\mathrm{Na}^{+}-\mathrm{H}^{+}$exchange is necessary for RhoA-induced stressfiber formation. J Biol Chem 271: 22281-22284

Wojciak B, Crossan J, Curtis ASG, Wilkinson CDW (1995a) Grooved substrata facilitate in vitro healing of completely divided flexor tendons. J Mater Sci: Mater in Med 6: 266-271.

Wojciak-Stothard B, Curtis ASG, Monaghan W, McGrath M, Sommer I, Wilkinson CDW (1995). Role of the cytoskeleton in the reaction of fibroblasts to multiple grooved substrata. Cell Motility Cytoskel 31:147-158.

Wojciak-Stothard B, Curtis A, MonaghanW, Macdonald K, Wilkinson C (1996) Guidance and activation of murine macrophages by nanometric scale topography. Exp Cell Res 223:426-435.

Wojciak-Stothard B, Denyer M, Mishra M, Brown RA
(1997) Adhesion, orientation and movement of cells cultured on ultrathin fibronectin fibers. In Vitro Cell Develop Biol Animal 33:110-117.

\section{Web references}

[1] URL http://blast.wustl.edu/blast/ncbi14ntfmt.html). Accessed 5/1999

[2]. URL http://helix.nih.gov/science/swissprot.html. Accessed 4/1999

[3] URL http://www.bjmu.edu.cn/bi/ncbitest/ 00000t0a.htm Accessed 5/1999

\section{Discussion with Reviewers}

D. Jones: The paper claims that chloride channels are important in mechanotransduction because if the authors inhibit them they do not see any effects of mechano-sensing. However, they have not shown that the effects on chloride are not dependent on calcium

Authors: The reviewer argues that we have not formally demonstrated that the particular type of cell used has chloride channels. We have not demonstrated by electrophysiological experiments that there are chloride channels that are stress responsive in our cell type. However, we have antibody, antisense, external chloride ion level, and evidence from a variety of chemical inhibitors that such channels are active. Furthermore though electrophysiological evidence for such channels has been published only for a few cell types the other types of evidence we have used have been accepted as compelling evidence that chloride channels are present in all eukaryote cells. The reviewer is also unimpressed with our argument that chloride channels (being at least in some cases threestate channels with paired channels) form the ideal system for making $\mathrm{x}-\mathrm{y}$ mechanical comparisons. This point can be viewed from the fact that cells respond to strain, i.e., make x-y comparisons.

The reviewer also argues that there is much evidence that strain receptors are calcium channels, and indeed there is, derived mostly from the use of the non-specific reagent gadolinium. Nevertheless this could be right and not inconsistent with our findings because many chloride channels are calcium-dependent (Curtis and Wilkinson, 1999).

D. Jones: There does not seem to be any argument presented that the stretch reception as mediated by the chloride channel is an early event in response to topography, although the authors do state why they cannot find direct evidence in their system.

Authors: The reaction is an end-point reaction so that differences between experimental treatments are maximal. Wojciak-Stothard et al. (1995b) showed that spreading reactions start within 5 minutes in controls. With the inhibitors we use they simply do not start or proceed very slowly.

D. Jones: The response to topography is, the authors claim, related to tensions associated with residence on the 
particular topography. Surely tensions will be selfgenerated by cells even on a planar surface? Are the tensions generated on the topographies studied known to be higher or lower than those generated on planar surfaces? This would appear to underlie the work described, if tensions are likely to be similar then the responses to topography would be unrelated to this factor.

Authors: The referee is correct that tensions will be, and indeed, clearly are, often generated on planar surfaces witness the early work by Harris (1982, text reference). But the topography will tend to concentrate tensions in particular regions of the cell as the cell conforms to the surface.

D. Jones: If tension is the cause of the behaviour on topography the authors would be able to engender the same cellular responses simply by applying conditions which raise the tension acting on the cells on planar surfaces. Have the authors done this? If so they should consider reporting these findings since they would help to validate their claims since it is obvious that these experiments do not alter tensions alone.

Authors: Oakley et al. (1997) have done the reverse experiment of lowering the tensions by depolymerising the cytoskeleton and when this is done reaction to topography is much reduced or can totally vanish.

\section{Additional References}

Curtis A, Wilkinson C (1999) New depths in cell behaviour: reactions of cells to nanotopography. Biochem Soc Symp 65: 15-26.

Oakley C, Jaeger NA, Brunette DM (1997). Sensitivity of fibroblasts and their cytoskeletons to substratum topographies: topographic guidance and topographic compensation by micromachined grooves of different dimensions. Exp Cell Res 234 413-424.

Wojciak-Stothard B, Madeja Z, Korohoda W, Curtis A, Wilkinson C (1995b) Activation of macrophage-like cells by multiple grooved substrata. Topographical control of cell behaviour. Cell Biol Int 19: 485-490. 